\title{
REFRACTIVE DEPTHS OF PASSION IN WUTHERING HEIGHTS: BRONTË, BUNUUEL AND BEYOND HUMANISM
}

\author{
Susan Pyke \\ University of Melbourne, Australia
}

\section{Abstract}

There is a counter-tradition to the Enlightenment project of silencing the sentience of country which can be traced from Romanticism to contemporary times. In 1858 Emily Brontë's novel Wuthering Heights introduced its readers to a Yorkshire moor of cradling flora, interventionist waters and ghost-accommodating winds. One hundred years later this brilliantly productive novel inspired Abismos de Pasión, ably directed by Luis Buñuel. Buñuel's film connects with Brontë's decentralisation of the human, demonstrating a similar conceptual openness to representing communicative exchanges between the human and non-human. Buñuel, like Brontë, resists the humanist project of silencing the non-human by the simple but powerful act of accepting that the other-than-human can be heard. The most recent Wuthering Heights film, directed by Andrea Arnold is made in this tradition. The animal and non-animal are given room to speak, highlighting the actant properties of the non-human, permitted in Brontë's novel. Such communications are instrumental if not reasonable, for they invite attentive audiences to listen in newly porous ways.

Keywords: Brontë's Wuthering Heights, Bunuel's Abismos de Pasión, sentience, Voicing the Non-Human.

\section{ABISMOS REFRACTIVOS DE PASIÓN EN CUMBRES BORRASCOSAS: BRONTË, BUÑUEL Y EL MÁS ALLÁ DEL HUMANISMO}

\section{RESUMEN}

Desde el Romanticismo hasta hoy en día se ha venido produciendo una contestación al silenciamiento sentiente de la nación que había caracterizado la época de la Ilustración. En 1858, la novela de Emily Brontë, Cumbres borrascosas, nos muestra un páramo de Yorkshire cuna de flora, agua siempre presente y viento fantasmagórico. Cien años después esta novela brillante y provechosa inspiró Abismos de Pasión, dirigida con habilidad por Luis Buñuel. Esta película encarna muy bien la descentralización de lo humano de Brontë, mostrando una amplitud conceptual similar, al representar los intercambios comunicativos entre lo humano y lo no-humano. Tanto Buñuel como Brontë contestan el proyecto humanista de silenciar lo no-humano simplemente al aceptar que lo más-que-humano pueda ser escuchado. Una película reciente sobre Cumbres borrascosas, dirigida por Andrea Arnold, continúa esta misma tradición. Ambos, lo animal y lo no-animal pueden ser escuchados, haciendo hincapié en las propiedades actantes de lo no-humano, tal como sucede en la novela de Brontë. Dichas comunicaciones son coadyuvantes, por lo menos razonablemente, de hacer que los lectores y los espectadores escuchen de formas novedosas y permeables.

Palabras clave: Cumbres borrascosas de Brontë, Abismos de Pasión de Buñuel, "sentiencia," dar voz a lo no-humano.

DOI: https://doi.org/10.25145/j.recaesin.2018.77.04

Revista Canaria de Estudios Ingleses, 77; november 2018, pp. 41-60; ISSN: e-2530-8335 


\section{INTRODUCTION}

Emily Brontë's Wuthering Heights is set in 1801, but was written in the rapidly industrialising northern England of the mid-nineteenth century. Over the ensuing one hundred and fifty years this memorable novel has garnered hundreds of adaptations. Most of these retell the tragic love story of the hyper-sensitive Cathy Earnshaw and her foster-brother Heathcliff, as complicated by a double triangulation formed by the less colourful Edgar Linton and his sister Isabella. I find little that is new in the hall of mirrors formed by such dull reflections, and prefer the more generative revisions that break through the limits of the tain, that dark expanse behind Wuthering Heights' glassy simulacrum. Such open adaptations offer readers startling refractions of the Yorkshire world that is so brilliantly lit in Brontë's novel. Working with Brontë's attuned representations of cradling heather, gurgling becks, ghostly winds and territorial dogs, these revisions move beyond human-centred storytelling, opening possibilities for nonhuman communications to make a different kind of sense to the human. I am interested here in two particular adaptations that go beyond the central plotline of Brontë's novel, to approach her text's openness to the nonhuman. The 1950s surrealist film, Abismos de Pasión, directed by Luis Buñuel, is a very different film to the contemporary remake by Andrea Arnold, but both works make explicit Brontë's implied acceptance of a sentient more-than-human world.

In Buñuel's film, one of twenty he made over two decades in Mexico, the nonhuman is present in sleetish rain, invasive wind and a massive ancient tree. Hunted vultures, pinned butterflies, a caged bird, sacrificed frogs and a slaughtered pig also speak, in different ways, through the film. As with Brontë's Wuthering Heights, where Cathy's relationship with Heathcliff is intrinsically linked to her relationship with the flora and fauna of the moors, Buñuel's Cathy (Catalina) and his Heathcliff (Alejandro) are part of, rather than central to the sweep of rain, the immensity of the landscape and the often put-upon nonhuman animals. At the same time, the nonhumans in Buñuel's text take on a presence of their own, forming a direct appeal to the audience's senses.

Arnold, too, gives significant screen time to the nonhuman. The first scene opens with a foreground of steady wind and rain. The same powerful moor weather, laced with birdsong, dominates the close of the film. Arnold extends Brontës representations of birds, rabbits and horses in ways that suggest subject positions not defined by the human. This willingness to let the nonhuman communicate on their own terms is reflected in her film's central motifs. The first is a black and white feather which floats according to currents that move beyond directorial design. Brontë's text can be felt here, through the lapwings that are preyed upon by Heathcliff until Cathy shows him the alternative of venerating dropped feathers. The second, a leafless branch, taps against the window, as does the ghostly branch that enters the dream of Brontë's Lockwood. As Arnold's film makes clear, the branch is also dancing to the breath of an arrhythmic storm. In both of these motifs the wind is agential, orchestrating its own timing, with matter playing along in its own key. Arnold's provisions for nonhuman agency to unfold its story through the frames of her film breathes new life into Brontë's novel. 


\section{GENRE CROSSING IN WUTHERING HEIGHTS TOWARDS POSTHUMAN INVOCATIONS}

As the attentions of Buñuel's and Arnold's adaptations suggest, Brontë's descriptions of the nonhuman make an allowance for two-way communications between the human and the nonhuman. This separates her work from the humanist traditions of her time. Even while her novel forms part of the first wave of groundbreaking realist novels, because of its close descriptions of Yorkshire farming and cooking, and its use of dialect, particularly through the voice of the not-so-servile Joseph, and also through the primary narrator Nelly, it is still inflected with a mutuality that include the sentient nonhuman. A more one-way communication marks the Romantic canon that includes Wuthering Heights for the triangulations of its love plot and its Gothic overtones of entrapment and the supernatural. The physical world in Brontë's novel moves outside Romanticism's humanist representations of a transformative Nature mediated by the human imagination for the benefit of human rhapsody, because in Wuthering Heights the nonhuman is present and agential on its own term. Winds wuther with or without Heathcliff and Cathy, as surely as the grass grows over their grave.

As Brontë's text crosses genres to allow the nonhuman to be repositioned as equal to the human, so too do the genre crossings in Buñuel's and Arnold's cinematic works go beyond a humanist orientation. Abismos de Pasión, one of the last films produced by Bunuel, reflects his respected position as a founder of the cinematic surrealist movement. At the same time, his film can be described, even derided, as a spaghetti Western. Similarly, while Arnold's Wuthering Heights is a romantic drama, not too far distant from other mainstream adaptations of Brontë's novel, it is also, through its temporal doubleness and reflective re-imagining of the past, typical of a neo-Victorian work. The unstable genre categories in these artworks suggest that conceptual openness and the posthuman perspective are compatible, if not essential, bedfellows.

I gather these three works together as posthuman for the ways in which they break free from a perspective that centres the human. As bioethicist Cary Wolfe explains, posthumanism refuses the harms that come with privileging the human (xvi-xvii). Wolfe's position has some sympathies with the theory of matter extended by cultural physicist Karen Barad, where humans exist in a 'multidimensional' state of co-existence with other species (142). This co-affectivity literally disturbs the human skin through an entrainment that joins the human and the nonhuman at a molecular level. I suggest here that posthuman texts can make this material entrainment more evident.

These possibilities fit with Freya Mathews' recent philosophical work on invocation. Invocation, Mathews suggests, is the most ethical way to improve human relations with the nonhuman, through its hospitable attention that is, to use Mathews' helpful term, ontopoetical ('An Invitation'). In the ontopoetic moment, human/nonhuman encounters are invited through a reciprocal close listening and intense watching. However, as the literary ecocriticism of Jonathan Bate makes clear, invocations do not necessarily suggest a 'fallacious ascription of feelings' to the non- 
human, for 'an invocation is not necessarily an ascription' (74). An invitation can be accepted, but it can also be refused and such responses are best not taken personally.

In this context of productive possibility, human representations of the nonhuman can be seen as worthwhile, but necessarily partial and opaque. Invocations offer a gentle augmentation because they host, rather than contain human/ nonhuman understandings. This applied attention to the nonhuman's capacity to communicate scales back the human story to just one strand of a world threaded through with meaningful narrations.

\section{ADAPTATIONS, SPECTATORS AND THE POSTHUMAN AFFECT}

With Mathews' ontopoetical conception in mind, operating under Bate's caveat, I explore the adaptations of Wuthering Heights offered by Bunuel and Arnold, to ask how the invocations in the cinematic works might extend those in Brontë's text. Modal factors are crucial here, for as Linda Hutcheon's adaptation theory makes clear, cinematic and written texts engage audiences' senses differently. Because the cinematic text directly activates aural and visual responses, it provides different possibilities for posthuman invocations. In watching these films, audiences may be able to extend the posthuman possibilities implicit in Brontë's Wuthering Heights because their senses are differently engaged.

To make this point, I must first stress that humans are bound to approach artworks from their own historically specific position. Sensory perceptions and imaginative flights are both tied to prevailing social norms and values. Because temporal contexts influence both textual production and reception, the implicit posthumanism in Brontë's novel, when revisited through the films of Bunuel, and then Arnold, is likely to be more influential on contemporary audiences beginning to question human centrality and supremacy. This repositioning is made possible through a historical continuum that stretches back, at least, to Brontë's time. Respect for the nonhuman is integral to Romanticism, even while such respect has traditionally served human interests.

This is not to say that my reading of Arnold's and Buñuel's films implies a posthuman directorial intention, any more than I would say Brontë's agenda was to decentralise the human. As Julie Sanders points out in her work on adaptations, the idea of authorial intention is a 'tricky domain' (81). While an adaptation, because it is an adaptation, will have some kind of intent, attributing a specific intention to these adaptations is as problematic as it would be for any other creative work. While only a handful of adaptations work with the posthuman elements of Brontë's novel, out of the many creative interpretations of this text, other individual motivations will also be at play for these adaptors. For example, as Hutcheon argues, the established audience for a classic text offers adaptations a commercial advantage (88). Buñuel was in difficult financial circumstances at the time he made his film, suggesting this imperative may have been important to him. There are also disadvantages in creating an adaptation. As Hutcheon puts it, adaptations always risk never being good 
'enough' $(84,86)$. Arnold speaks directly to this point; 'everyone who has read it has already effectively filmed it in their mind. Presenting your own vision against all that is a bit mad' (Lodge). Intent is complex and messy, as many artists themselves will attest, as they struggle to explain the motivations that lie behind their work.

It can be said, however, that an attachment to the source text is likely to be a partial motivation for an adaptor. Adaptation theorist Rachel Carroll writes to this point, if perhaps a little too emphatically. 'All adaptations express or address a desire to return to an 'original' textual encounter' which relates to 'a cultural compulsion to repeat' (1). Arnold speaks to this desire for repetition. 'I'd always had this thing about the book and wanted to have a go' (Lodge). A return, driven by attachment, seems to have also been part of Bunuel's motivation, given that Harvard's film archive describes Abismos de Pasión as a 'cherished project' he nurtured over two decades. Thus, while I do not suggest Buñuel or Arnold created their work through a posthumanist agenda, both films seem to be motivated by an attachment to the source text. It is not possible to say whether or not this attachment is connected to the posthuman spaces Brontë leaves in her text, but it is worth pointing out that these spaces are repeated in these adaptations.

The attachment these two directors have to Brontë's Wuthering Heights is likely to be shared with at least some of the audience who choose to respond to their works. According to Sanders' adaptation theory, an enriched and knowing audience - those who are familiar with the source text - can read an adaptation in ways that involve both 'expectation and surprise' (25). This knowingness involves, Sanders suggests, a 'complex system of filtration' made up of various 'intertextual webs or signifying fields' (24). These 'signifying fields' create specific intertextual connections that are as impossible to describe as directorial intentions. I note, however, for the adaptations I consider here, that the spectator's 'knowingness' may not relate to the source text itself. It is likely that many audiences of these two adaptations will not have read Wuthering Heights. All the same, they are likely to be aware of the cultural activity around the title and the author, and will have expectations about the plot and the setting. Such expectations may or may not relate to the posthuman inflections I find in the novel. It depends on the readers' filters.

Sanders' concept of this filtered 'enriched knowingness' resonates with Jacques Rancière's philosophical argument for the spectator's 'ignorance' (11). As Ranciëre convincingly argues in a spirit of inclusion, spectators are bound by the past experiences that they bring to a text, including previous readings as well as their lived past. All spectators' responses are 'ignorant' in specific ways, bound by internalisations of what has been previously read, watched, heard, smelt, felt and even tasted. Appreciating the impact of the past experiences that a spectator brings to an artwork has important implications for posthuman reception. If, as Rancière argues, an artwork creates a questioning pause, perhaps because it is open enough to invite some measure of interpretation, it might intercept 'the general distribution of ways of doing and making', opening newly conceptualised modes of being (13, 15). This shift has the potential to disrupt the way that spectators understand the nonhuman world. The moments in these two films, where the nonhuman is given space, points towards such new conceptions. These this may or may not be mediated 
through an 'expectation' seeded by a pre-existing relationship to Brontë's novel. It is true that Brontë brilliantly immerses the reader's imagination through the affect the weather, the birds, the dogs and the sky have on her characters. However, the films offer differently powerful invitations to take a more posthuman position because audiences' auditory and visual senses are more directly engaged. These intermedial and cross-cultural texts represent the nonhuman in ways that might further influence audiences' conceptions of co-affectivity and encourage them to question human mastery. Accepting this co-affectivity will be dependent on the readiness of the audience to be moved by nonhuman non-actors through their auditory and visual senses, as well as through their imagination.

My understanding that such possibilities lie within the text and the readied spectator is underpinned by the notion of an emotive transmission from the nonhuman to the human. This concept is shaped by Bracha Ettinger's explanation of how artworks can facilitate a degree of permeability between audiences. For Ettinger, the unspoken pre-Archaic allows for a shared affect that crosses the skin in moments when audiences are mutually moved by a work of art. This co-affectivity is made possible, she argues, by a partial subjectivity formed through the shared affect between the in-utero child and the expectant mother. Co-affectivity is one of the first things humans learn. Ettinger conceptualises this shared affect as a matrixial borderspace, a space where audiences move together, beyond the utterance, in a shared response. As Judith Butler explains, in her foreword to Ettinger's text, such responses are tonal, rather than representational (xi). The communications to be had are close to, yet beyond signification.

Ettinger's insight applies to the posthuman affect in these cinematic texts. As audiences consider the sentience of the nonhuman, this shared affect can encourage not only an awareness of human-to-human entrainment, but also an entrainment between humans and nonhumans. Audiences who have already experienced this co-affectivity will bring this knowingness -this ignorance- into their reception.

I suggest then, that when Wuthering Heights is presented in the cinematic mode, at least in the two films discussed here, audiences' aural and visual senses might be activated in ways that can heighten an affective awareness of the nonhuman. Buñuel's discomforting visual imagery, and Arnold's amplification of nonhuman sound and movement, allow, in different ways, new spaces for human/nonhuman communications.

This co-affectivity does not involve a mysteriously invoked shared language. Rather I argue, with cultural theorist Wendy Wheeler, that nonhuman communicative exchanges are implicit in the undulations of human speech. In Wheeler's account of a biosemiotics informed by the experiential, language is dependent on the 'substrate, the body and its sensory ways of apprehending the world', and this makes verbal language 'entirely dependent' on the 'creaturely world' (23). I further temper this idea of a 'creaturely' correspondence, where nonhumans might respond to human invocations, with Barad's 'agential realism'. While human/nonhuman communications are 'specific causal material enactments', changes that follow 'may or may not involve' human input (171). Human sovereignty can never be assumed when the nonhuman is so strange to the human. However, language, including the 
visual imagery of film, can be a bridge between the human and nonhuman in a world populated, but not mastered by the human, creating an affect that is deeply sensory, even while it is historicised. This posthumanist theoretical position, which brings affect theory together with new materialisms, informs my reading of these two remarkable adaptations, through Brontë's unforgettable Wuthering Heights.

\section{ATTENDING TO THE NON-ANIMAL UTTERANCE}

When Arnold was shooting her film in England's Yorkshire dales, the constant presence of the wind influenced her creative direction by 'rattling the windows' and 'whistling through trees' (Lodge). To those familiar with Brontë's text, the interactivity Arnold experiences recalls the wuthering moor in the novel. During her last desperate days, Brontë's Cathy draws succour from the snow-laced wind, opening her sickroom's window towards the death she desires. Cathy's willingness to give her life to the nonhuman, rather than working to negate its agency to support her own, suggests a posthuman position.

This encounter, where Brontë's Cathy invites the wind in through her window and her body, has a human/nonhuman mutuality that is also found in Arnold's representation of Cathy. Arnold's Cathy opens herself to the music of the wind as she sits, in communion with Heathcliff, on the tip of a crag, presenting her early pregnancy, and equally manifest childhood self, to the moor. There is much in her stance and her silence that is ontopoetical. Through the attention of her body, Arnold's Cathy invokes the nonhuman and in doing so, she invites audiences to do the same.

In the story of Wuthering Heights, both in the source text and its revisions, communicative weather often manifests, sometimes in the form of warm airstreams such as those on the crag, but more often in rain, sleet and snow. In one of Brontë's most memorable scenes, there is a powerful interchange between the materiality of weather and the discourse of metaphor in her depictions of Cathy and Heathcliff's willingness to be 'drenched' and 'soaked' in the weather of the moor (85). At this critical point in Brontë's story, when Heathcliff appears to leave Cathy to Edgar, an intense thunderstorm does damage to the fireplace of the childhood home shared by Heathcliff and Cathy, forming cracks in this space that nurtured their blossoming adolescent love. The gale of Cathy's distress as she is blown about with new desires and responsibilities shapes the granite shale of Heathcliff's heavy devotion, and this imbues the storm with metaphorical strength; it stands for the lovers' powerful and tempestuous relationship. Metaphor has been applied more explicitly earlier in this scene, through Cathy's famous declaration of love.

My love for Linton [Edgar] is like the foliage in the woods: time will change it, I'm well aware, as winter changes the trees. My love for Heathcliff resembles the eternal rocks beneath: a source of little visible delight, but necessary. (82) 
At the same time, the text allows for more. Soon after the lightning strikes and the chimney cracks, Heathcliff enters this weather and Cathy runs behind him, 'bonnetless and shawlless to catch as much water as she could with her hair and clothes' (85). It is this active human/nonhuman encounter which materialises metaphor. As ecocritic Pippa Marland argues, neuropsychology wires humans for thinking through the 'as'. Metaphor is much a part of human senses as hearing and sight, offering a helpful route for humans to approach the stories proffered by the nonhuman.

At the same time, materially, the stone-faced Heathcliff and the windwraithed Cathy dissolve the boundaries of individual subjectivity as they enter the moor, accepting rather than resisting the rain and wind that is part of their home. There is the familiarity of kinship in their willingness to be of the moor in all weathers, without judgement, and with acceptance. This openness suggests the invocation Mathews describes, where the human orients to the nonhuman, to enhance shared material relations. Brontë makes this 'openness from closure' (Wolfe, $\mathrm{xx}$ ) clear through her counter example of Lockwood, the bumbling first narrator who frames Cathy and Heathcliff's story. Lockwood abhors Yorkshire's winter moors, preferring biddable babbling brooks and balmy breezes to the snow and mud he cannot master. Despite his distaste for 'misty and cold' weather, he forces himself on the moors (9). If there is an active encounter to be had, his strenuous effort to uphold human centrality means there is no affect for Lockwood, only effect. When it comes to Lockwood, the nonhuman of the Yorkshire moor keeps its own counsel.

Just as the weather's vernacular is heard, or not, by Brontë's characters in different ways, so too do responses vary for the characters in Buñuel's and Arnold's films. There is, however, an addition in these cinematic texts. The weather is also heard (or not heard) by the films' audiences, offering the potential for posthuman interpretations that are as unpredictable but as present as the currents of air and water that are part of the makings of weather's rain and wind.

Bunuel offers a beautiful refraction of the weather that separates yet enjoins his film to Brontë's novel, in his tain-breaking portrayal of Alejandro walking through a downpour towards Catalina. Both Alejandro and the rain are held distant from all that is human. Lit windows, encasing his object of desire, hold him out, as they hold out the weather. Alejandro does not fight the deluge like Lockwood. Instead, like Brontë's Heathcliff and Cathy in the thunderstorm, the rain and Alejandro flood together. The water falls with him, on him, through him (see Figure 1).

The rain is similarly accepted by Arnold's young Heathcliff. As he walks towards his new home, opened to him by Cathy's generous father, his humanity is backgrounded through the loud beat of the rain. The damp enters the step of his heavy human feet as he wades through the slush of mud, tussocks pushing back at his tread. He works his way through the soaked earth, like all the other groundbased matter of the moor. His alertness to the intensity of the nonhuman keeps him scaled to the depths of this scene, even while the gloaming clouds and evening birdcalls connect with him through the spread of the rain.

Arnold continues to give space to the weather, specifically the wind, in her powerful re-enactment of Heathcliff's attempted exhumation of Cathy. In Brontë's 


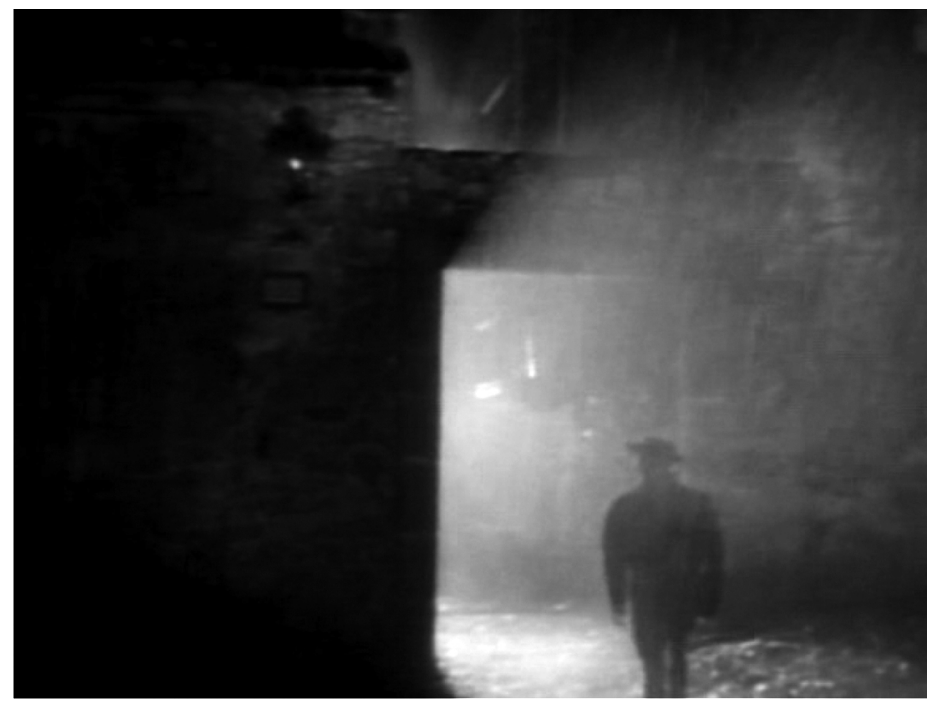

Figure 1: Rain and Heathcliff, seeking a course (Buñuel 1954).

novel, Heathcliff only gives up his 'labour of agony' (190) when he senses Cathy's presence in the movement and sound of the wind above her grave. Heathcliff listens and responds, leaving Cathy's remains to the wind. So, too, does Arnold's Heathcliff. The spirited Cathy is part of the shifting swirls of the earth Heathcliff disturbs but also -and this is a departure hosted by the cinematic mode- the particles of dirt make their own presence felt. The earth and the wind react to Heathcliff and, at the same time, they play their own game to the side.

There is an interplay between metaphor and materiality in both films when the wind is mediated by curtains. For Buñuel, the ghostly Cathy, carried in a wind that took away Heathcliff's need to recover her body, is present in a moving curtain that ushers her into the weather (see Figure 2). Metaphorically, the curtain pulses with Catalina's short breath and her impending death. At the same time, materially, the specificities of the Mexican wind create an unsettling distance between the film and the book. This is not the cold winter wind that entered the failing lungs of Brontë's ailing Cathy. This shift from the novel's wintry Yorkshire to the film's sultry Mexico is emphasised through a shot of lovesick Alejandro looking over a heat struck landscape. It is a different wind that moves through Catalina's curtains, a searing heat has entered the moor of Wuthering Heights. This dissonance might be enough to create Hutcheon's 'surprise', or Rancière's interception; audiences may pause, and attend differently, while the curtain rises and falls with its own intent. This is a new exchange that goes beyond Brontë's text. The Mexican wind sings its own side note, like the wind that lifts and drops the dirt that has soaked in the remains of Arnold's Cathy, according to its own currents. The unexpected within 


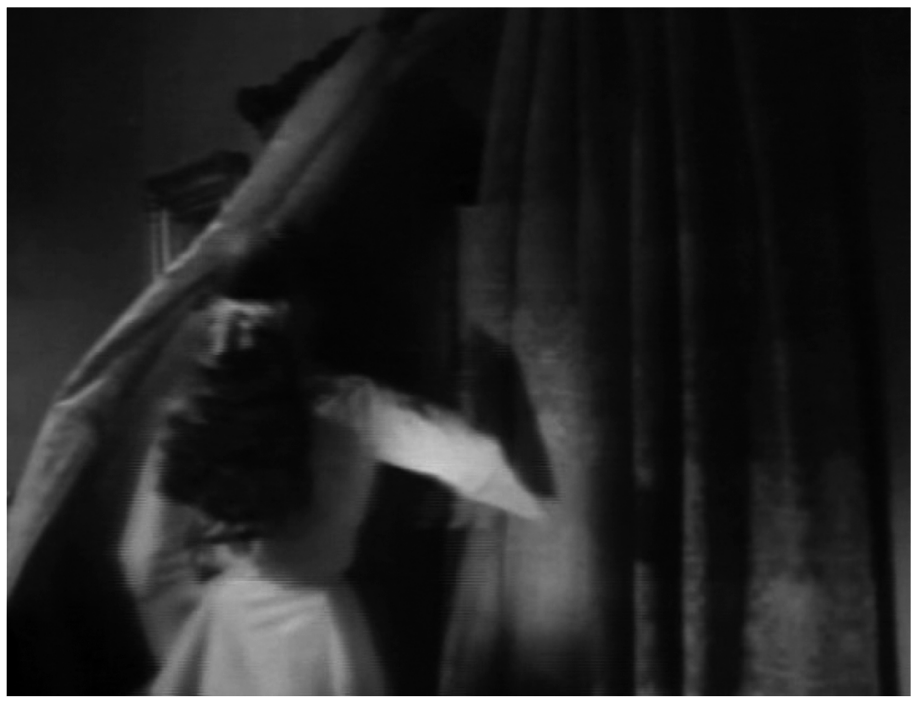

Figure 2: The wind breathing in, Catalina breathing out (Buñuel 1954).

the expected provides an opportunity for the posthuman to be felt through the curtain call itself.

Like the free-flowing curtain in Buñuel's film, a breeze-filled curtain in Arnold's Wuthering Heights also welcomes the unpredictable activity of the wind. However, Arnold turns Brontë and Bunuel's perspective around to depict a window curtain that breathes out to Heathcliff, as he hunkers around the external wall of the room that contains the dying Cathy. Perspectives, like the wind, will not be contained. The wind 'speaks' from inside the house. Arnold's Heathcliff pauses, attends, and comes to a decision in response to this communication. This shift also invites the audience to wonder about the wuther of the wind, generated within the house. The skin of human habitation may not be as closed as it first might appear. As well as giving screen time to the wind and rain, Buñuel's film also attends to the earthy fauna of Brontë's moor. Anthony Frogola's film criticism perceptively celebrates the way Buñuel's 'subterranean motion' of roots 'pierce the external constraints of the material world' (54). The film is grounded in roots, textual, psychological and physical, from the first frame of Abismos de Pasión (Figure 3). Bunuel's privileging of this tree's extraordinary presence at the outset foreshadows its importance in a later scene, where the two lovers return to their childhood devotions in one of the trunk's nooks. There is more to this scene than a metaphorical returning to a shared past. As film critic Saviour Catania notes, Buñuel's placement of Alejandro and Catalina amongst 'a massive tree's cavernous roots' evokes the immense presence of Penistone Crag and the spread of heath. It is these places that foster the 'twofold oneness' between Cathy and Heathcliff (273). This allusion to 


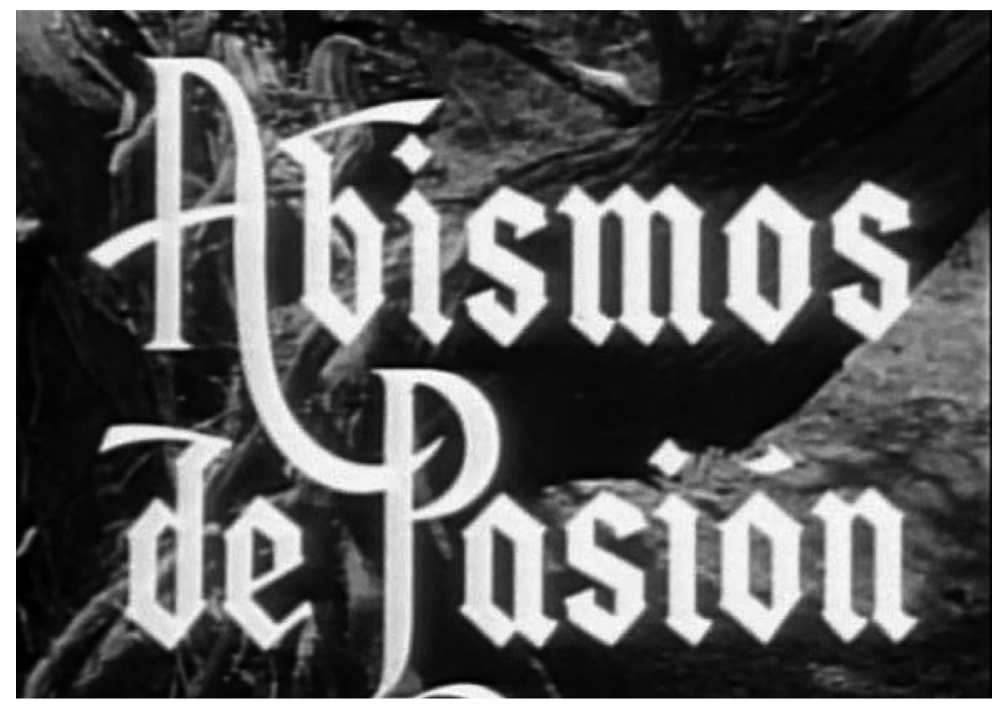

Figure 3: Title roots (Buñuel 1954).

Heathcliff's and Cathy's shared (if partial) subjectivity can be extended to include the tree. Its dominance suggests an active mutuality. The tree intervenes, it is Catalina and Alejandro as Cathy 'is' Heathcliff in Brontë's novel (82). The way Buñuel privileges the tree equally with human characters in his film demonstrates -as does his footage of wind and rain -that unfleshed matter need not necessarily be represented as under the dominion of the human. Such boundaries might appear to be maintained in humanist discourse but this is not, as this film clearly shows, materially the case. Buñuel's film goes further than Brontë's text, and it does this because where the novel evokes the presence of the flora of the moor through human affect, in the film the audience has access to a physically induced posthuman perspective through their own visual senses. The tree's material presence dominates the frames where it appears.

Buñuel's willingness to leave space for the tree's presence demonstrates the particular posthuman opportunities provided by film. As film critic Anat Pick puts it, film has the ability to create 'equality between matter' because of the open lens of the camera (115). As with the wind and the rain, Bunuel's text gives the tree equal framing, providing an opportunity for the audience to see matter differently, and, perhaps, less hierarchically. This is even more emphatically the case for cinematic representations of the nonhuman animal. 
The agency Brontë assumes for the wind and rain of the moor is also present in her depictions of nonhuman animals. In the first chapter of Wuthering Heights, town-bred Lockwood mistakes a 'heap' of dead rabbits for an 'an obscure cushion full of something like cats' (52). His inattentiveness earns the scorn of his would-be love object, Cathy's daughter Catherine, consolidating the reader's understanding of Lockwood's self-centred humanity. He fails to sensibly comprehend other animals, just as he is insentient to weather, heather and bog. Brontë's subtle questioning of dominant anthropocentric perceptions of nonhuman animals are picked up and extended in Bunuel's Abismos de Pasión and Arnold's Wuthering Heights.

Much of Bunuel's founding work in surrealist cinema, where art is taken outside the realm of human consciousness, dealt with the relations between the anima and the animal. ${ }^{1}$ His powerful response to Freudian psychoanalysis involved creating a visual and aural excess that entered into the unconscious of the audience. This effort is particularly apparent in the nightmarish scene of sacrifice, where $\mathrm{Bu}$ nuel's farmhand José (Brontë's Joseph) throws frogs into a pot of boiling water. This disturbing rite occurs in company with Jorge (Brontë's Hareton), the redemptive Earnshaw of the generation that follows Cathy and Heathcliff. Jorge's mesmerised gaze coaxes the audience to be acutely aware of the frogs suffering the ministrations of José and his straw cross. For Frogola, this scene is metaphorical, speaking to the 'sacrifice' and 'death' to be suffered by Alejandro (54). In this interpretive context, José's orchestration of this frog-sacrifice can be further read as a critique masterful self-aggrandisement that legitimises ideas of human dominion over the nonhuman. In building on Brontë's characterisation of Joseph as a sanctimonious bible-citing yeoman, Buñuel's resists the deathly focus of conservative Christian hermeneutics of morbidity, lambasted in Grace Jantzen's feminist theology for its privileging of masterly humanist patterns of oppression over natality that silence alternative cyclic and generative theologies present in more radical and posthuman Christian interpretations.

At the same time, materially, the frogs speak for themselves. Their lifeless legs, bulging with muscles formed from movements that are no longer possible, make the cruelty of human mastery apparent, and the incongruity of José's prating prayer makes this positioning questionable. The frogs, for the considerable length of this scene, make themselves felt. It is not just the hand of religion dangling the abject above the burning furnace (Figure 4). The film, at a material level, shows limp frogs undergoing inexplicable and painful deaths.

${ }^{1}$ I note, as caveat to this claim, that Buñuel scholar, Julie Jones, has argued Buñuel's earlier treatment, developed in the 1930s, bears little resemblance to this later film. For Jones, only the initial treatment strongly represents his work with Salvador Dali. Without being able to make this comparison, I limit myself here to noting Buñuel's film as drawing upon surrealism's tradition. 


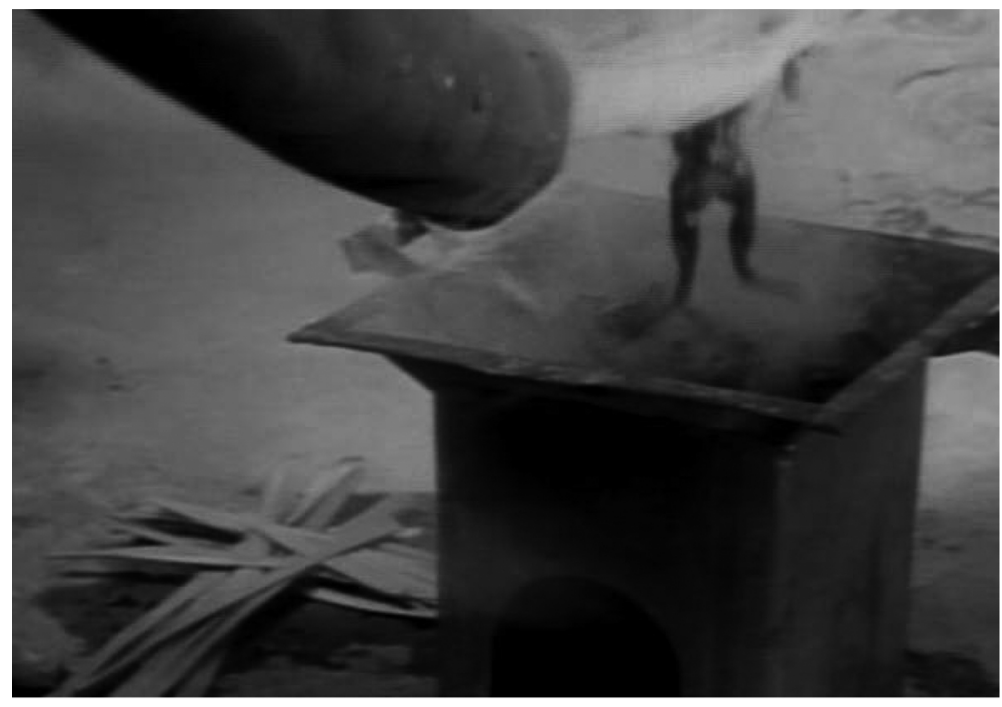

Figure 4: Joseph’s unmoving sacrifice (Buñuel 1954).

This invitation to question human mastery, both from Buñuel, and the animals themselves, is repeated in a scene where a pig is dragged to the killing bench. The shadow-shrouded pig's actions speak to the flick of the slaughterman's sharpened knife. There is a resistance in the pig's feet, rooted in the ground against three men and a rope. The pig makes its own scene, albeit directed, with a protracted squeal, a silence, and then, most profoundly, in its absence in the next frame. Again, Frogola speaks to this as metaphor, referencing Alejandro's claim that he would slit his own throat like a pig if Catalina didn't care about his decision to marry Isabel (55). However, the pig is doing anything but holding the knife. The metaphor holds some sway, but the pig also creates its own story (Figure 5), inviting audiences into a posthuman ontopoetic moment.

Buñuel's images of potted frogs and a throat-slit pig will make some audiences pause. Building on Jonathan Burt's seminal Animals in Film, art historian Diana Donald argues that cinematic representations of 'the suffering and death of animals has a unique potency' unattainable through words, because the visual image is 'uniquely capable of ambivalence' (53). As Burt puts it, the image of the animal in film can never be read as artificial because nonhuman animals rupture such a reading through the opening allowed for them by film. Burt calls this opening, created by the nonhuman non-actor, the 'split' in the animal image (163). The camera's gaze, to an extent, centres the human, but the possibilities of displacement are equally present because the nonhuman animal is not acting.

This split does not occlude the metaphorical impetus of Buñuel's work - it strengthens it. As Buñuel scholar Julie Jones points out, the use of animals in Abismos 


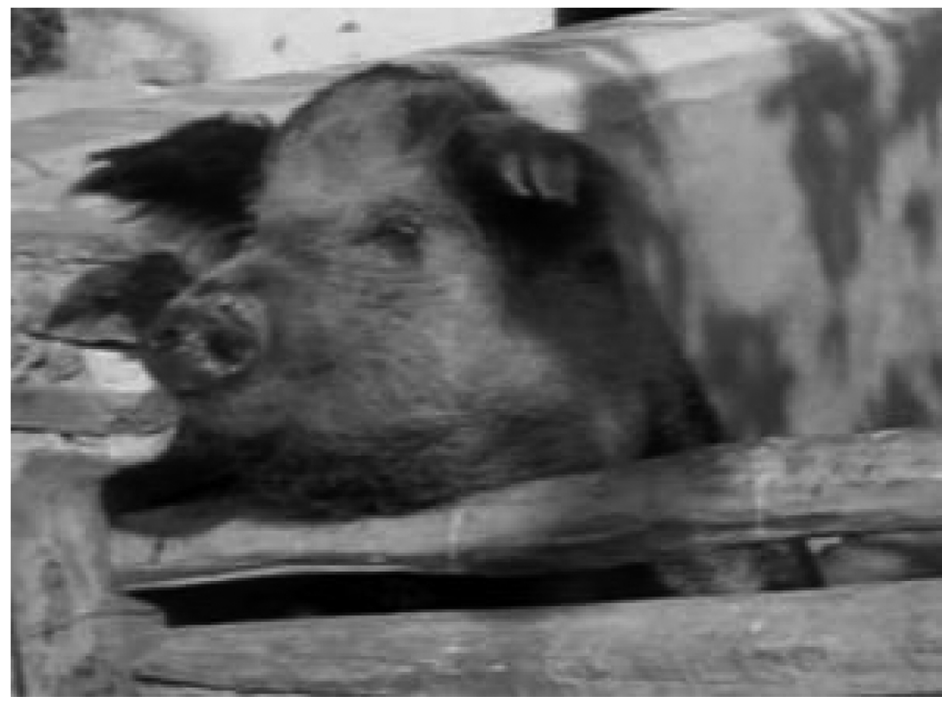

Figure 5: The shadowed pig (Buñuel 1954).

de Pasión retell human animal instincts, human animal passions. The metaphorical anima gives impetus to Burt's split, feeding the displacement that marks the posthuman perspective. The pig's eyes, closed to pain, can also be understood in terms of the fleeing Isobel, hands over her ears. Her shared fate with the pig is important and so too is her empathy for the pig. Such scenes may well foster a spectatorial discomfort with the slaughter of animals for human use. Literary critic Robert McKay puts it this way; the representation of killing animals makes 'explicit just how far ideology and presumption condition our conception of animals' (206). Audiences watching Abismos de Pasión are invited to question this 'ideology' and these 'presumptions' through visual and auditory communications that are partly directed by Bunuel and partly enacted - but not acted- by the animals themselves. The 'knowing' or 'ignorant' spectator might have their expectations met, but they might also be surprised. In this receptive state, audiences are invited to reconceive the posthuman possibilities present in Brontë's Wuthering Heights, if hosted by the 'ignorances' formed by that which they have previously read or experienced. For example, I relate the swooning Isabel and the unmoved Alejandro to Brontë's Heathcliff, at least in his attempt to hang a yapping dog to cover up his elopement with Isabella. I also relate the scene to farm-based slaughters that I have witnessed. Other audiences will bring their own ignorance, their knowingness, to this scene. Meanwhile, the pig does its own work. While the gaze of the camera is held by the human, within Buñuel's metaphoric frame, the scene allows nonhuman/human communications to occur outside his direction. It is this split in the image that gives Abismos de Pasión its earthy depth. 


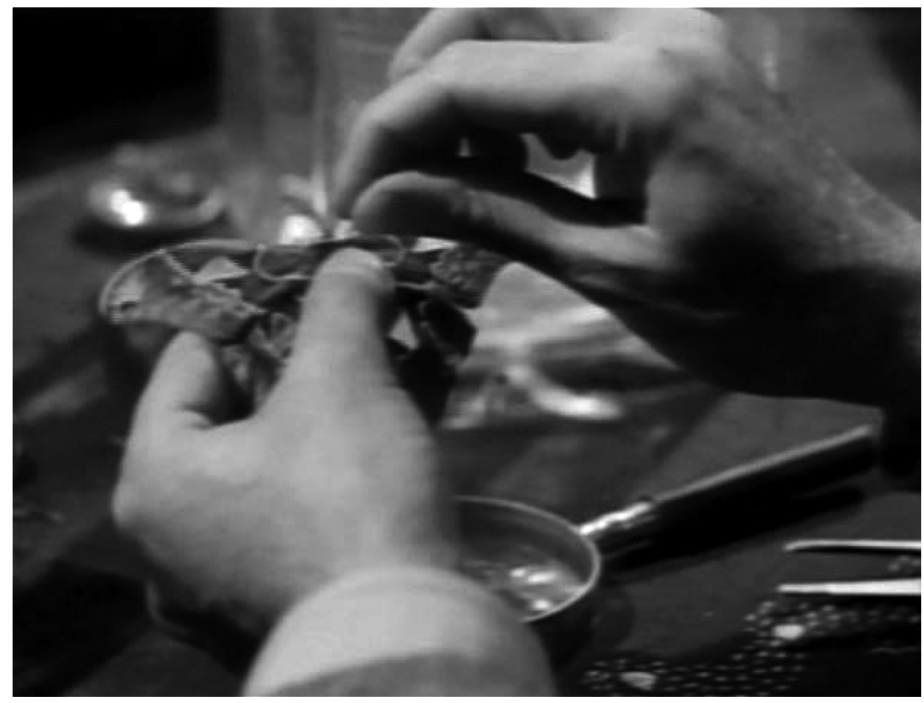

Figure 6: Pinning, wing under the thumb (Buñuel 1954).

This posthuman spilt can also be found in refractions of the winged. Buñuel foreshadows the death of the frogs and the pig, in his first scene through a quarrel between Catalina (Cathy) and Eduardo (Edgar). Vultures scatter from their perch on a dead tree at the sound of a gun, just before Catalina enters the study, gun in hand. Eduardo is busy pinning down live butterflies with more ease than he pins down Catalina (Figure 6). When Catalina supports Isabel's criticism of his butterfly collection, he points to a bird she keeps in a cage. She slaps the bars hard enough for the bird to fall off its perch and tells Edgar she keeps the bird encaged for love. The fraught differentiation between capture and death, a cage and a pin, opens the question of human mastery. Just as Eduardo holds the pin, Catalina controls the catch to the cage and the gun. Animals, the caged, the pinned and the shot, are important presences in Buñuel's film from the first.

Arnold also engages her audience with questions that surround the entrapment and slaughter of nonhuman animals through a caged bird, a canary, its wings beating against the bars. Again this can be read as a metaphor, with the bars standing as bonds of oppression, the force that underlies possessive love. Arnold has prepared her audience for seeing the limits in this bird's life through the opening scene of Heathcliff's arrival, where the human is scaled to grounded limits of signification while other winged creatures escape, through the unfixable split in the artificial image, into the toss of the wind. The freewheeling flights of birds on the moor are repeated in childish drawings, presumably done by Cathy. These alternative representations press against the caged bird as it reflects on itself, doubles itself then grows out of the cage into its shadow. It performs both with and beyond the 
humanist frame of metaphor, the partial freedom of its uncaged shadow making the body behind bars all the more contained.

The tension between capture and death resonates with questions around the human right to oppress the nonhuman. This is made explicit in the scene where Arnold's Nelly plucks a foot-hung domesticated duck, repeating Bunuel's José's morbid boiling of frogs and the pig that squeals and then is silenced with the flash of a butcher's knife. Soon after, Arnold's Heathcliff goes rabbiting, slinging the corpses he gathers over his shoulder, holding a live rabbit still as he watches Cathy and Edgar at a distance astride horses, sovereign, over the nonhuman, the grounded and Heathcliff. Snap goes the rabbit's neck. Arnold's camera witnesses this death, metaphorically, materially, just as the camera has previously lingered on Nelly's business-like de-feathering of the dead duck. Arnold, like Buñuel, leaves openings for the animals to speak through the stiffening of their bodies, even as the rabbit's stilled body tell a metaphoric story about the demise of life-filled love. Human mastery of other humans is the main story being told here, but this plot is enmeshed with broader modes of oppression where nonhuman deaths are horrific on their own terms.

This is not to assume that representations of butchered animals will make all audiences pause. For some, the representations of non-human animals in the work of Bunuel and Arnold will be no more than simple reflections of Wuthering Heights's farm-based realism. For me, it is significant that Buñuel's film devotes considerable screen time to gun-hunted vultures, pinned butterflies, a caged and battered bird, straw crossed frogs and a butchered pig, and that Arnold also provides lengthy representations of animals that are captured or slaughtered. While I am not ascribing a directorial intent here, as the inherent limitations and cruelties in masterful death are communicated through the animals themselves, the cinematic mode does allow audiences to extend the posthuman possibilities in Brontë's text both in and through the interventions made possible by the disturbing split created through the nonhuman image. The directors may or may not intend these nonhuman interventions, but they host these possibilities, and in this sense they invoke them.

\section{POSTHUMAN HOSPITALITYY AS THE GIFT OF ATTENTIVENESS}

Perhaps in response to her times, Arnold goes further than questioning ideologies and presumptions that relate to capturing and killing nonhuman animals. Some of her scenes move toward ideas of human/nonhuman mutuality. In the early stages of her film, Arnold's Cathy invites Heathcliff into the stable. She renders him voiceless, as he watches her watch him watching her feel the interior of a horse's ears. She is intimate, knowing and attentive. Cathy and the horse are sharing a sensual mutuality that reaches out to Heathcliff. He participates through his gaze. Cathy slips on the bridle like an embrace, her caress lifts the softness of the horse's lip so she might thread the bit like a stroke. There is both mastery and attentiveness in Cathy's hands. The audience is invited to know the horse, and Cathy, and Heathcliff 
as complicit yet oppressed individuals, for while Heathcliff and Cathy look at each other, the non-acting horse looks into the camera. Seeing the horse in a specific subject position, even as it responds to the human touch, even while -or perhaps because- it will be bridled, saddled, ridden, creates an opening for co-affectivity beyond the plotline. This scene will be replayed when an older Heathcliff watches Nelly tie Cathy into a corset.

Arnold returns to the possibilities in equine/human relations, introduced through Cathy's touch, at the end of the film, after Cathy's death. There is a long shot of Heathcliff, prone and brooding, as he is so often in this film. This time he is in heather. The camera pans in closer, he grinds his boot in the root-busy dirt, breaks the blooms with his hand. He is working against the nonhuman like Brontë's Lockwood, inattentive in his singular subjecthood, morbidly savaging his partial namesake. There is none of the natalistic connection to heather that Brontë's Cathy experiences in her dream of an earthy heaven made manifest through the smell of flowering heather. Then a horse comes into the frame. Heathcliff stares aloft. The horse stops, heavy hooves inches from Heathcliff's face. There is violence in Heathcliff's inattention. The horse walks away, then gently returns, nose-nudging Heathcliff, communicating a continued willingness for exchange. Despite Heathcliff's refusals, the horse continues to invite Heathcliff to engage, even as Heathcliff refuses to reciprocate.

The potential for increased co-affectivity between humans and nonhumans, implicit in Brontë's text, is made beautifully present in the different possibilities presented by Arnold through this gentle horse. Such scenes might encourage audiences to listen to the nonhuman more attentively, taking nonhuman communications more equally into account. Such are the interventions required to disrupt the masterful relationships humans have with the physical world. To entertain the possibility of nonhuman sentience is to let go of limiting self-centred humanity.

I find hope in these progressions, where the openness to the nonhuman present in Brontë's novel expands into Buñuel's surreal nonhuman focus, then blossoms into the intersubjectivity that occurs in Arnold's film. These increasingly posthuman texts allow for unexpected communications with the nonhuman in ways that add to a growing movement towards more reciprocal human/nonhuman relations. For me, the scenes that involve non-signified moments of encounter are particularly moving when there is a split in the non-human animal image, but I also celebrate where these texts allow for nonhuman sentience in the wind, the earth and its flora. As Mathews has demonstrated, when the human is ready to listen to the nonhuman, mutual encounters may flourish in unexpected and mutually beneficial ways (Reinhabiting, 21). A readiness to listen, nurtured through the non-human images and sounds in these two films, might well create narratives from a pig's resisting feet, from birdsong working with the wuthering wind, from a tree's heavy barked age and from a horse's grace. Such stories will be mediated through human eyes and ears, made meaningful through human imagination, perhaps assisted through metaphor, but they are stories told by the nonhuman.

Buñuel's and Arnold's films offer unpredictable but constant human and nonhuman communications through attentive directorial spaces that allow such 
encounters with the wind, the rain, a big-bellied tree, frogs, a pig, canaries, vultures. lapwings, a duck, rabbits and a curious horse. These posthumanism inflections have the potential to elicit a human response to nonhuman communications, despite the films' differences in content and context. Buñuel's and Arnold's films refract that which is posthuman in Brontë's novel, allowing the nonhuman to speak beyond the affect on human characters, particularly when their films' nonhuman non-actors speak directly to the audience. Nonhuman matter, of its own accord, with and beyond directorial fiat, finds ways to nudge through receptive human skin to create its own relations of affect. Of course, this posthuman affect, felt through the pause in audience reception, is caged in signification. These two films are inspired by the written word and framed by directorial decision making. It is promising, however, despite this limitation, that these films offer increased recognition of nonhuman sentience, giving audiences ever expanding opportunities to take a more natalistic perspective. The attentive attunement of these directors, inspired by the spaces Brontë leaves for the nonhuman, allow audiences, like the rain and wind on the moor, to flow into opportunities that involve acting differently.

Reviews sent to author: 20 April 2018 Revised paper accepted for publication: 6 June 2018 


\section{WORKS CITED}

Abismos de Pasión. Dir. Luis Buñuel. Perf. Irasema Dilián, Jorge Mistral, Lilia Prado.Prod. Oscar Dancigers. Mexico, 1954.

BARAD, Karen: Meeting the Universe Halfway: Quantum Physics and the Entanglement of Matter and Meaning. Durham: Duke University Press, 2007.

BAtE, Jonathan: Romantic Ecology: Wordsworth and the Environmental Tradition. London and New York: Routledge, 1991.

Brontë, Emily: Wuthering Heights. 1847. Ed. Pauline Nestor, London: Penguin Books, 1995.

BurT, Jonathan: Animals in Film. London: Reaktion Books, 2002.

Carroll, Rachel: Adaptation in Contemporary Culture: Textual Infidelities. London: Continuum, 2009.

Catania, Saviour: "Wagnerizing Wuthering Heights: Buñuel's Tristan Storm in Abismos de Pasión". Literature/Film Quarterly 36: 4 (2008): 272-280.

Donald, Diana: "Pangs Watched in Perpetuity: Sir Edwin Landseer's Pictures of Dying Deer and the Ethos of Victorian Sportsmanship." Animal Studies Group. Killing Animals. Urbana and Chicago: University of Illinois Press, 2006.

EtTinger, Bracha: The Matrixial Borderspace. Minneapolis and London: University of Minnesota Press, 2006.

Frogola, Anthony: "Buñuel's Revision of Wuthering Heights: The Triumph of L'Amour Fou over Hollywood Romanticism." Literature Film Quarterly 22 (1) 1994, 50-56.

Harvard Film Archive: “Buñuel's Mexico.” 2012. Downloaded 19 January 2013, http://hcl. harvard.edu/hfa/films/2012julsep/åBuñuel.html.

Hutcheon, Linda: A Theory of Adaptation. London and New York: Routledge, 2006.

Jantzen, Grace: Becoming Divine: Towards a Feminist Philosophy of Religion. Bloomington and Indianapolis: Indiana University Press, 1999.

Jones, Julie: "Fatal Attraction: Buñuel's Romance with Wuthering Heights." Anales de la Literatura Española Contemporánea 22: 1/2 (1997): 149-163.

Lodge, Guy: "Interview: Andrea Arnold on Wuthering Heights." Hitfix2012. Downloaded 19 January 2013, http://www.hitfix.com/in-contention/interview-andrea-arnold-on-wutheringheights-crying-to-mumford-sons-and-having-faith-in-a-face\#918O5TUKO8ILAWlk.99.

Marland, Pippa: “My Cries Heave, Herds-Long': A Reading of Metaphor in Gerard Manley Hopkins' 'Terrible Sonnets' through the Lens of 'Animot Posthumanism." Fifth EASLCE Conference: Natural Loquens University of Tenerife, 28 June 2012.

Mathews, Freya: "An Invitation to Ontopoetics: the Poetic Structure of Being." Australian Humanities Review 43 (2007): 1-14.

Mathews, Freya: Reinhabiting Reality: Towards a Recovery of Culture. New York: State University of New York, 2005.

McKaY, Robert: “BSE, Hysteria and the Representation of Animal Death.” Animal Studies Group. Killing Animals. Urbana and Chicago: University of Illinois Press, 2006.

Pick, Anat: Creaturely Poetics: Animality and Vulnerability in Literature and Film. New York: Columbia University Press, 2011. 
Ranciere, Jacques: The Emancipated Spectator. Tran. Gregory Elliot. Verso: London, 2011.

SANDERs, Julie: Adaptation and Appropriation. London and New York: Routledge, 2006.

Wheeler, Wendy: The Whole Creature: Complexity, Biosemiotics and the Evolution of Culture. London: Lawrence and Wishart, 2006.

Wuthering Heights: Dir. Andrea Arnold. Perf. Solomon Glave, Shannon Beer, James Howsen, Kaya Scodelaria, Prod. Robert Bernstein, Douglas Roes, Kevin Loader. Ecosse Film Productions: Film 4 with Goldcrest Film Productions, Screen Yorkshire and HanWay Films, 2011. 